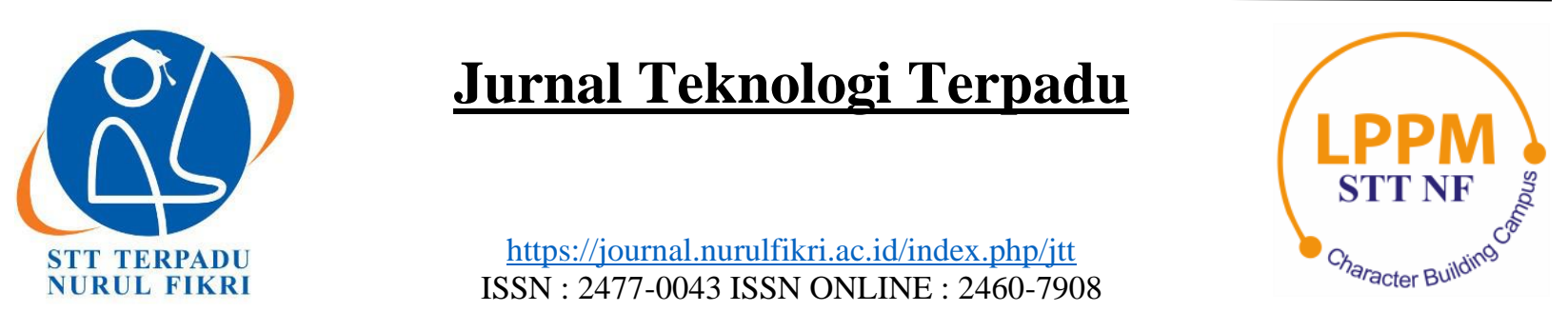

\title{
IMPLEMENTASI KENDALI INTENSITAS CAHAYA LAMPU DENGAN INTERNET OF THINGS BERBASIS ARDUINO UNO MENGGUNAKAN METODE FUZZY LOGIC
}

\author{
Ramdani $^{1}$, Marisa $^{2}$, Carudin $^{3}$ \\ ${ }^{1,2}$ Teknik Informatika STMIK Bani Saleh \\ ${ }^{3}$ Manajemen Informatika STMIK Bani Saleh \\ Bekasi, Jawa Barat, Indonesia 17113 \\ ramdaniabenk2013@gmail.com,ichaich28@yahoo.com, carudin2905@gmail.com
}

\begin{abstract}
The light intensity setting of the lamp uses the on-off principle for setting the lighting of the lamp. Therefore, the on-off principle base on the dark or lightroom conditions without being affected by the environment. Such conditions result in ineffective and inflexible use of electrical energy. Therefore, changing the light intensity control system from a manual system to an automation system is necessary by implementing the fuzzy logic method as a light intensity controller. The main component of light intensity control using Arduino Uno Microcontroller with data input through AC Light Dimmer sensor and Bluetooth HC-05 is part of the hardware. In contrast, software design uses mobile programming algorithm with APP INVERTOR 2 application and Arduino IDE application. The following weaknesses of the system are made that is how to determine the method of parameter assessment, where the system becomes unstable due to the response to the change of response is very fast and has a small parameter value. This study aimed to create one of the electronic control devices of light intensity control, which the process carried out includes setting the intensity of the lamp freely through a Bluetooth connection of an Android smartphone with the Arduino UNO microcontroller as an electric current regulator on the lamp by the AC Light Dimmer module.
\end{abstract}

Keywords: Microcontroller, AC Light Dimmer, HC-05, APP INVENTOR 2, Android

\begin{abstract}
Abstrak
Pengaturan intensitas cahaya lampu umumnya dilakukan dengan menggunakan prinsip menyalakan-mematikan untuk pengaturan penerangan lampu. Untuk itu pada prinsip menyalakan-mematikan tersebut didasari pada kondisi ruangan gelap maupun terang, tanpa dipengaruhi oleh lingkungan. Kondisi seperti ini mengakibatkan tidak efektif dan tidak fleksibel pada penggunaan daya listrik, sehingga dibutuhkan perubahan sistem pengendali intensitas cahaya dari sistem manual ke sistem otomatisasi dengan menerapkan metode fuzzy logic sebagai pengendali intensitas cahaya lampu. Sebagai komponen utama pengendali intensitas cahaya lampu menggunakan mikrokontroler arduino Uno dengan inputan data melalui sensor AC Light Dimmer dan Bluetooth HC-05 merupakan bagian dari perangkat keras, sedangkan perancangan perangkat lunak menggunakan algoritma pemrograman mobile dengan aplikasi APP INVERTOR 2 dan aplikasi Arduino IDE. Berikut kelemahan dari sistem yang dibuat yaitu cara menentukan metode penilaian parameter, dimana sistem tersebut menjadi tidak stabil dikarenakan respon pada perubahan respon yang sangat cepat dan mempunyai nilai parameter yang kecil. Tujuan dari penelitian ini yaitu untuk membuat salah satu alat pengendali elektronik kendali intensitas cahaya lampu, yang mana proses yang dilakukan meliputi pengaturan intensitas lampu secara bebas melalui koneksi bluetooth dari smartphone Android dengan mikrokontroler Arduino UNO sebagai pengatur arus listrik pada lampu oleh modul AC Light Dimmer.
\end{abstract}

Kata kunci: Mikrokontroler, AC Light Dimmer, HC-05, APP INVENTOR 2, Android

\section{PENDAHULUAN}

Salah satu faktor yang meliputi bagian dari kondisi intensitas cahaya dalam penglihatan yang baik berawal dari pengaruh penerangan dalam melihat benda atau objek di depan mata merupakan bagian dari penerangan yang baik. Apabila hasil penerangan cahaya sangat bagus maka hasil 
yang didapat tentunya akan terlihat secara jelas dan cepat dalam pencarian tanpa menimbulkan kesalahan yang berarti [1]. Penggunaan saklar $O N$ dan $O F F$ merupakan sistem pengaturan yang sangat umum dipakai dalam penerangan cahaya lampu pada ruangan. Dimana saklar tersebut bekerja kondisi ruangan gelap. Ketika kondisi diluar mendung dan lampu dalam keadaan menyala sebagai penerangan di ruangan akan terasa silau karena terlalu terang dan apabila penerangan dipadamkan kondisi ruangan akan gelap. Pengguna terkadang sering melupakan hal ini, terkadang lupa mematikan lampu pada saat meninggalkan ruangan tersebut. Sehingga berdampak pada penggunaan listrik yang tinggi dan menjadikan pemakaian listrik yang tidak efisien. Pada kasus seperti ini terdapat aturan Jika-, maka yang terdapat pada fuzzy logic yang berfungsi sebagai mendefinisikan karakteristik sistem operasi yang lebih baik kedepannya [2].

Dengan ini penulis ingin membuat salah satu alat elektronik untuk mengatur intensitas cahaya lampu. Dimana proses yang dilakukan meliputi pengaturan intensitas lampu secara bebas melalui koneksi bluetooth dari Android dengan mikrokontroler Arduino UNO sebagai pengatur arus listrik pada lampu oleh modul AC Light Dimmer [3]. Setelah menguraikan latar belakang secara rinci maka lahirlah rumusan masalah yaitu bagaimana rancang bangun sebuah sistem kendali intensitas cahaya lampu pada ruangan, bagaimana pengaturan intensitas pencahayaan lampu menggunakan smartphone Android melalui koneksi bluetooth, dan apakah peran fuzzy logic dapat diimplementasikan sesuai yang diharapkan.

Terdapat ruang lingkup yaitu sistem hanya membahas tentang kendali intensitas pencahayaan pada lampu, dimana lampu yang dibutuhkan menggunakan lampu bohlam 5 watt yang merupakan bagian dari kendali intensitas pencahayaan lampu. Penulis menggunakan smartphone Android melalui koneksi bluetooth. Pada uraian tujuan dari penelitian bagaimana membuat dan merancang sebuah alat kontrol intensitas cahaya lampu dalam ruangan, merancang dan merealisasikan pengendali intensitas cahaya lampu ruangan dan membuat aplikasi Android untuk pengendali intensitas cahaya sesuai kebutuhan pencahayaan yang dibutuhkan.

\section{TINJAUAN PUSTAKA}

2.1 Logika Fuzzy Model Sugeno

Logika fuzzy adalah bagian dari pembentuk soft computing. Logika fuzzy pertama kali ditemukan oleh Prof. Lotfi A [2]. Pada Model Sugeno logika fuzzy berfungsi sebagai keanggotaan Singleton. Untuk Orde 0 dengan rumus :

$$
\begin{aligned}
& \operatorname{IF}(x 1 \text { is a } 1)^{\circ}(\mathrm{x} 2 \text { is } \mathrm{A} 2)^{\circ} \ldots{ }^{\circ}(\mathrm{xn} \text { is An }) \\
& \text { THEN } \mathrm{z}=\mathrm{k},
\end{aligned}
$$

Dengan Ai adalah himpunan fuzzy ke-i sebagai anteseden (alasan), ${ }^{\circ}$ adalah operator fuzzy (AND atau OR) dan $\mathrm{k}$ merupakan konstanta tegas sebagai konsekuen (kesimpulan). Sedangkan rumus Orde 1 adalah:

$$
\begin{aligned}
& \operatorname{IF}(x 1 \text { is a } 1)^{\circ}(\mathrm{x} 2 \text { is } \mathrm{A} 2)^{\circ} \ldots{ }^{\circ}(\mathrm{xn} \text { is An }) \\
& \text { THEN } \mathrm{z}=\mathrm{p} 1 * \mathrm{x} 1+\ldots+\mathrm{pn} * \mathrm{xn}+\mathrm{q},
\end{aligned}
$$

Dengan Ai adalah himpunan fuzzy ke i sebagai anteseden, ${ }^{\circ}$ adalah operator fuzzy (AND atau OR), pi adalah konstanta ke i dan q juga merupakan konstanta dalam konsekuen.

\subsection{Mikrokontroler}

Menurut Sumarsono dkk. [4] Mikrokontroler adalah suatu IC (Integrated Circuits) dengan kepadatan yang sangat tinggi, dimana semua bagian yang diperlukan untuk suatu kontroler sudah dikemas dalam satu keping, biasanya terdiri dari CPU (Central Processing Unit), RAM (Random Access Memory), EEPROM/EPROM/PROM/ROM, I/O, Serial \& Parallel, Timer, Interrupt Controller.

Secara umum pengertian dari komputer, mikrokontroler adalah sebuah alat yang mengerjakan instruksi-instruksi yang diberikan kepadanya. Artinya, bagian terpenting dan utama dari suatu sistem terkomputerisasi adalah program itu sendiri yang dibuat oleh seorang programmer. Program ini menginstruksikan komputer untuk melakukan jalinan yang panjang dari aksi-aksi sederhana untuk melakukan tugas yang lebih kompleks yang diinginkan oleh programmer.

\subsection{Arduino}

Menurut Feri Djuand [5] untuk pemahaman Arduino yaitu kita harus mengerti apa itu physical computing. Physical computing merupakan sebuah sistem pembuat atau bisa disebut sebagai perangkat fisik dengan menggunakan software dan hardware yang mempunyai sifat interaktif dimana bisa menerima rangsangan dari lingkungan dan merespon balik rangsangan tersebut [6].

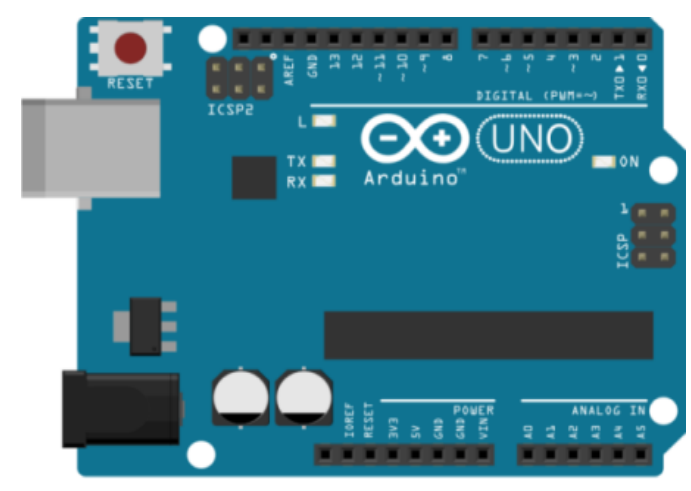

Gambar 1. Arduino UNO

\subsection{Modul AC Light Dimmer}

Pada modul ini untuk pengaturan daya listrik bolak balik / AC bisa menggunakan TRIAC. Dengan cara merubah besaran phase listrik AC dan mengatur waktu penyulutan TRIAC pada mikrokontroler. 


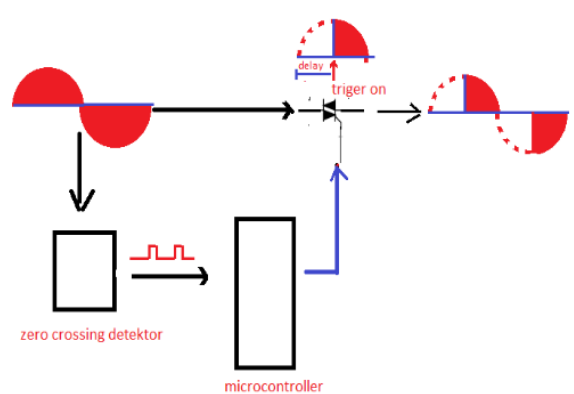

Gambar 2. Cara Kerja Triac untuk Mikrokontroler

Penentuan titik nol sinyal AC untuk memulai delay atau yang disebut dengan Zero Crossing Detector dimana akan menginterupsi mikrokontroler saat sinyal AC pada posisi 0 . Misal yg kita pakai INT0 (interrupt ekternal 0). Uraian tahapannya sebagai berikut: pada saat sinyal AC menuju titik 0, maka zero crossing detector memberi sinyal interupsi ke pin INT0 mikrokontroler. Mikrokontroler menjalankan program interupt servis rutin INT0.

Program servis rutin INT0 berisi delay dan output untuk men-trigger gate TRIAC. Besarnya nilai delay menentukan daya yg disalurkan oleh TRIAC. Besarnya delay $5 \mathrm{~ms}$ seperti contoh gambar dibawah ini artinya setelah $5 \mathrm{~ms}$ micon akan men-trigger TRIAC .

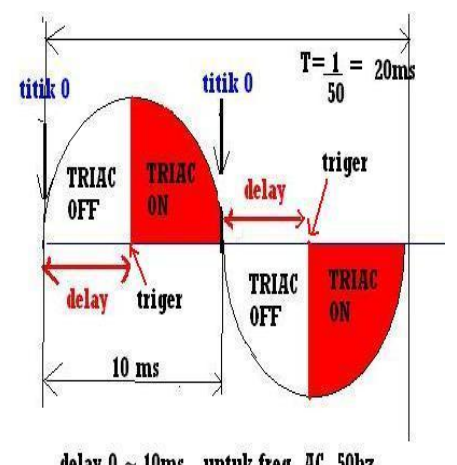

delay $0 \sim 10 \mathrm{~ms}$, untuk freq $A C \cdot 50 \mathrm{hz}$

Gambar 3. Besarnya Delay untuk Frekuensi AC 50 hz

Di bawah ini merupakan gambaran persentase pengaturan daya listrik AC sebagai berikut:

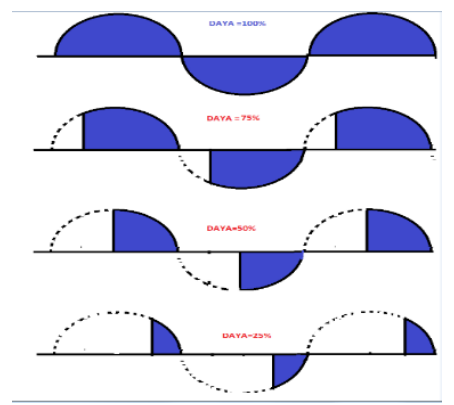

Gambar 4. Persentase Pengaturan Daya Listrik AC

\section{METODE PENELITIAN}

Pada bab ini merupakan uraian dari tahapan penelitian yaitu terdapat dua perancangan perangkat keras dan lunak.

\subsection{Tahapan Penelitian}

Pada penelitian menggunakan metode Fuzzy Logic Controller (FLC) dimana sistem fuzzy dapat diaplikasikan secara khusus dalam sistem kendali. Representasi dari Fuzzy Logic Controller (FLC) berfungsi sebagai operator dan mengoperasikan kendali plan/sistem dengan sistem kendali [7]. Beberapa alasan dipilihnya metode Fuzzy Logic Controller (FLC) dalam penelitian ini diantaranya:

1) Fuzzy controller mengakomodasi pengetahuan pakar dan operator.

2) Perbandingan penggunaan antara fuzzy controller dengan pengendali PID lebih kuat karena fuzzy controller dapat mencakup daerah operasi yang lebih luas dari pada pengendali PID dan dapat bekerja dengan lingkungan yang ber-noise (sinyal pengganggu).

3) Cost implementasi fuzzy controller lebih murah dari pada membangun pengendali berdasarkan model yang lainnya.

4) Modifikasi fuzzy controller lebih mudah dan dimengerti dalam pemodifikasian aturan - aturan lainnya.

5) Pemahaman pada fuzzy controller sangat mudah untuk dipahami dari sisi kinerja dan bagaimana cara merancang dan mengaplikasikannya dalam sistem nyata.

6) Sistem yang kurang stabil bisa dikendalikan oleh fuzzy controller.

\subsection{Perancangan Perangkat Keras}

Pada rangkaian sistem dibawah ini dijelaskan bahwa Arduino UNO sebagai sistem control pengendali utama sistem kendali. Sebagai kendali otomatis Arduino mendapatkan input dari 2 sensor, yaitu sensor gerak sebagai inputan pertama untuk mendeteksi pergerakan dan selanjutnya Arduino memberikan perintah kepada sensor cahaya untuk memberikan nilai intensitas pada ruangan, sehingga didapatkan nilai intensitas untuk memberikan pencahayaan ke lampu sebagai penerangan ruangan.

Selanjutnya yaitu sebagai kendali manual melalui perangkat smartphone Android dengan koneksi bluetooth melalui media Bluetooth HC-05 [8]. Saat Arduino mendeteksi adanya koneksi bluetooth maka kedua sensor akan berhenti sementara, karena nilai intensitas yang dibutuhkan Arduino untuk menyalakan lampu akan diatur oleh user pada aplikasi Android.

Pada gambaran rangkaian sistem pada Gambar 5, bahwa kuantitas pencahayaan sumber penerangan lampu akan besaran listrik disebut rangkaian Dimmer. Rangkaian dimmer ini merupakan satu bagian untuk mereduksi arus cahaya yang keluar dengan mengatur daya untuk nyala lampu. Dan fungsi utamanya yaitu menggunakan prinsip pengaturan tegangan, arus, sudut penundaan maupun pengaturan Pulse Width Modulation (PWM). 


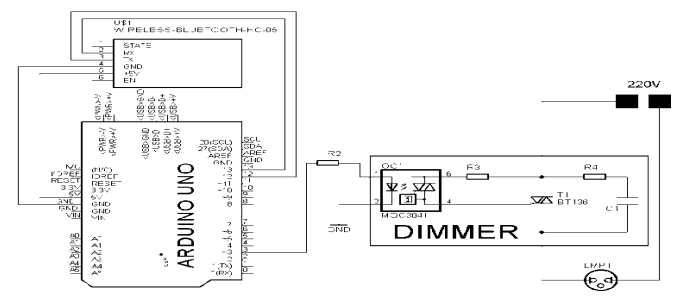

Gambar 5. Blok Diagram Rangkaian Sistem Kontrol

\subsection{Perancangan Perangkat Lunak}

Pada sistem yang dirancang terdapat perancangan perangkat lunak yaitu terdapat pemrograman sistem cerdas dan mobile. Pemrograman cerdas berfungsi sebagai pemrograman yang dianggap lebih pintar dan lebih cepat sehingga menghasilkan output yang diharapkan.

Sedangkan fungsi pada pemrograman mobile yaitu bagaimana merancang sebuah aplikasi untuk smartphone yang yang berfungsi sebagai pengendali sistem baik secara manual maupun otomatis. Aplikasi yang digunakan yaitu aplikasi App Inventor 2. App Inventor 2 merupakan bagian dari perangkat lunak sumber terbuka yang menggunakan antarmuka grafis dan memungkinkan pengguna aplikasi ini untuk men-drag and drop objek visual untuk menciptakan aplikasi yang dapat dijalankan pada sistem operasi Android [9]. Pada gambar di bawah ini merupakan contoh block pemrograman App Inventor bertujuan untuk menampilkan menu pada sistem pengaturan intensitas cahaya suatu ruangan. Sedangkan untuk pemrograman sistem cerdas terdiri atas algoritma dan diagram alir yang masing-masing aksi penerangan pencahayaan tergantung pada pembacaan input parameter intensitas cahaya pada suatu ruang.

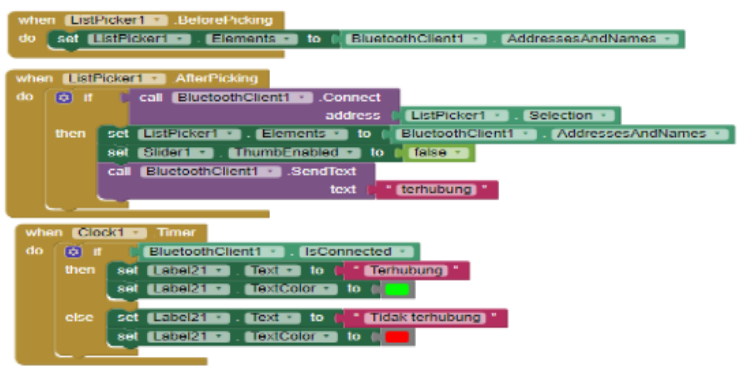

Gambar 6. Block Pemograman APP INVENTOR

\section{HASIL DAN PEMBAHASAN}

\subsection{Implementasi Sistem}

Berikut merupakan bagian dari tahapan implementasi sistem dimana perancangan sistem yang telah dibangun. Dengan mengkonfirmasikan perancangan program kepada user yang nantinya sebagai masukan pada sistem yang dirancang [10]. Di bawah ini merupakan uraian dari tahapan implementasi dari sistem yang dirancang yaitu paling utama mempersiapkan sebuah perangkat Arduino UNO. Setting Modul Bluetooth HC-05, pengujian Modul AC Light
Dimmer, membuat code program sistem kontrol di Arduino IDE, dan membuat Aplikasi Android menggunakan MIT App Inventor.

Pada langkah selanjutnya yaitu membuat komunikasi pada aplikasi Android dan Arduino dengan setting modul Bluetooth HC-05. Konfigurasi dilakukan dengan masuk ke mode AT-Command berfungsi sebagai bagian dari perintah komunikasi dengan serial port, dalam hal ini penulis akan mengatur status modul ke mode slave (sebagai penerima), baud rate dan mengatur password.

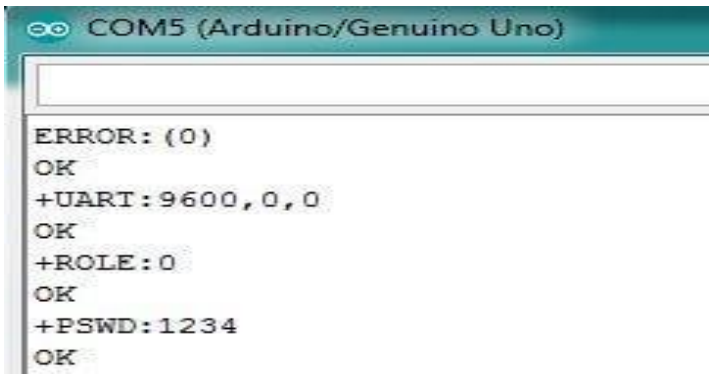

Gambar 7. AT-Command Modul

\subsubsection{Uji coba Modul AC Light Dimmer}

Rangkaian Dimmer berfungsi sebagai pengatur intensitas cahaya lampu melalui pengaturan gelombang tegangan jalajala PLN. Rangkaian Dimmer mencakup TRIAC yang dikendalikan oleh Arduiono UNO.Berikut Pengujian yang dilakukan untuk mengatur intensitas lampu menggunakan Modul AC Light Dimmer:

1) Kondisi Nyala Lampu Redup

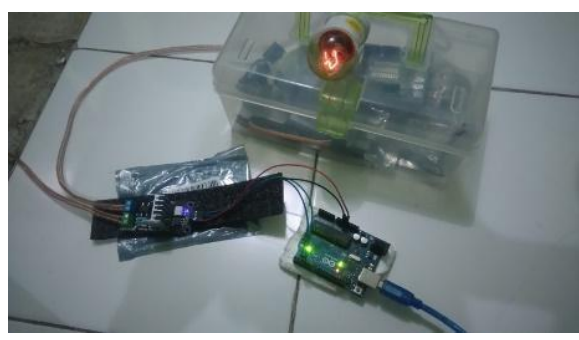

Gambar 8. Intensitas Nyala Lampu Redup

2) Kondisi Nyala Lampu Agak Terang

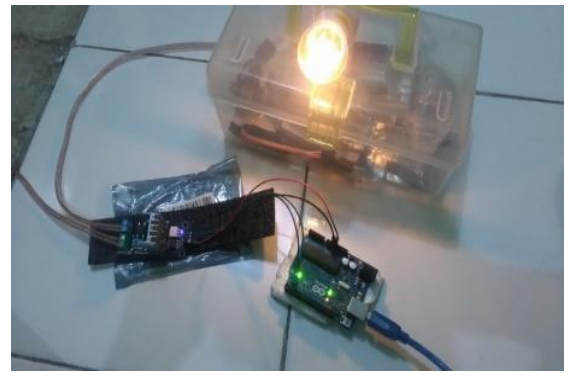

Gambar 9. Intensitas Nyala Lampu Agak Terang

3) Kondisi Nyala Lampu Terang 


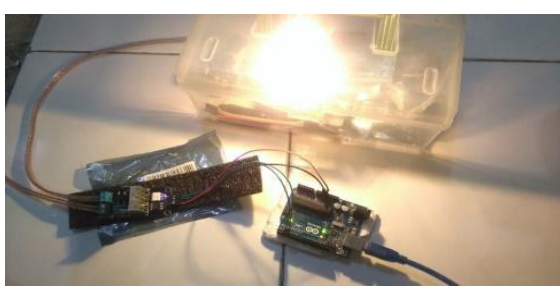

Gambar 10. Intensitas Nyala Lampu Terang

4) Kondisi Nyala Lampu Sangat Terang

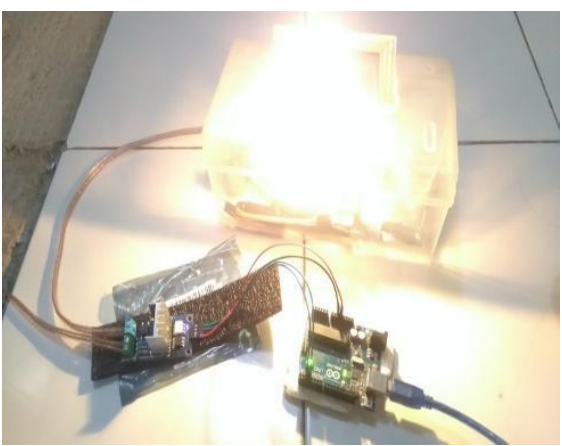

Gambar 11. Intensitas Nyala Lampu Sangat Terang

\subsubsection{Membuat Code Program Sistem Kontrol Arduino} IDE

Setelah pengujian sudah selesai, maka langkah selanjutnya adalah implementasi sistem kontrol pada Arduino UNO, Pada tahap ini pengkodean pada Arduino IDE.

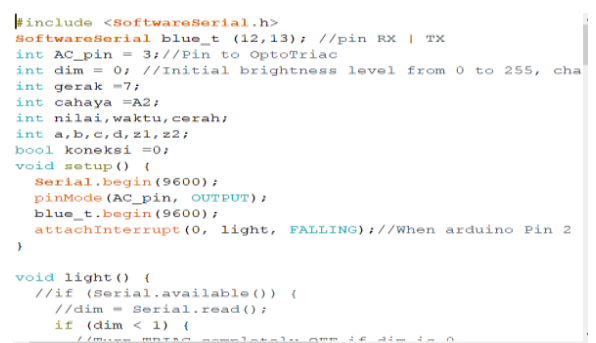

Gambar 12. Code Program Inisialisasi Pin Arduino UNO

Dari gambar diatas merupakan source code program untuk inisialisasi masing-masing pin pada sensor dan modul Arduino dan memberikan nilai variabel untuk masingmasing fungsi pada program Arduino untuk menjalankan kendali pada sensor-sensor dan module sehingga dapat berkomunikasi sesuai yang diinginkan.

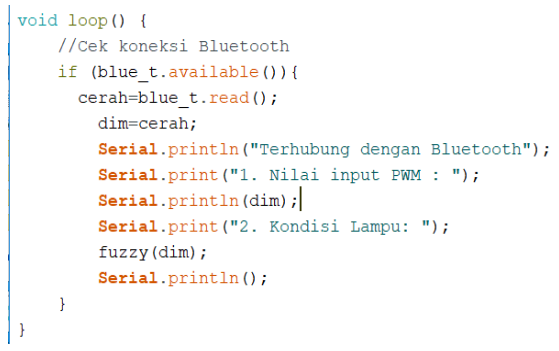

Gambar 13. Code Program Fungsi Berulang untuk Arduino

Dari gambar diatas merupakan code program untuk membaca hasil nilai variabel input dan output pada Arduino secara berulang, yaitu untuk selalu membaca nilai input dan output pada modul bluetooth, lalu dikonversikan ke dalam nilai PWM untuk menentukan kecerahan lampu.

\subsubsection{Implementasi Aplikasi Mobile menggunakan MIT App Inventor}

Aplikasi Android dengan MIT App Inventor merupakan kombinasi pembuatan aplikasi Android dan Arduino. Dimana tool yang digunakan antara lain App Inventor for Android. App Inventor ini mengaplikasikan antarmuka grafis yang memungkinkan pengguna menyusun dan dragdrop "blok" dalam membuat aplikasi secara sederhana tanpa menulis program/coding. Berikut tampilan dan visual blok programming yang dibuat:

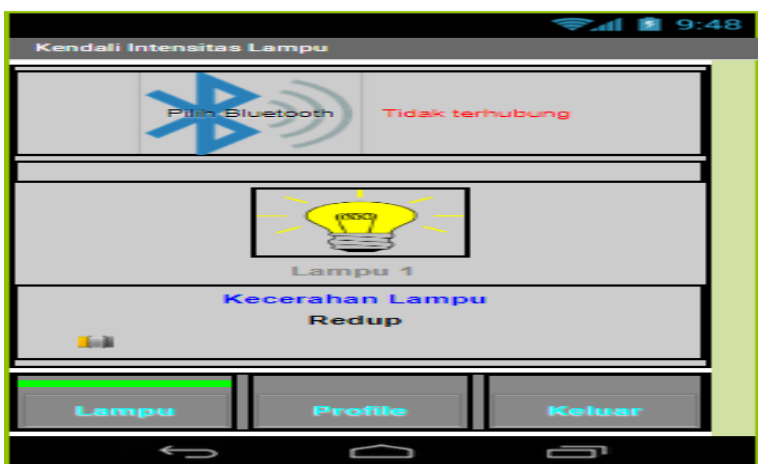

Gambar 14. Tampilan Menu Utama pada Android

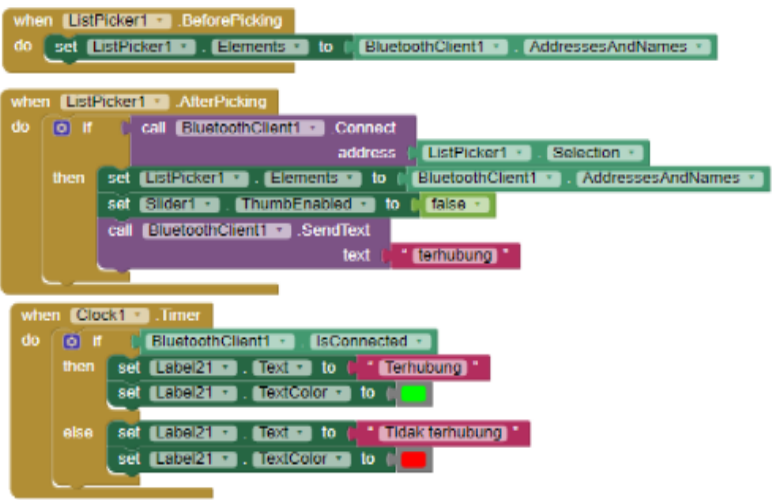

Gambar 15. Blok Programming untuk Koneksi Bluetooth

Dari gambar di atas menjelaskan saat kondisi sebelum Android melakukan koneksi ke bluetooth, yaitu akan menampilkan list bluetooth yang sedang aktif dan blok programming saat Android koneksi dengan bluetooth, Android akan terkoneksi dengan Bluetooth HC-05, lalu mengirimkan text "terhubung" ke Arduino UNO. 


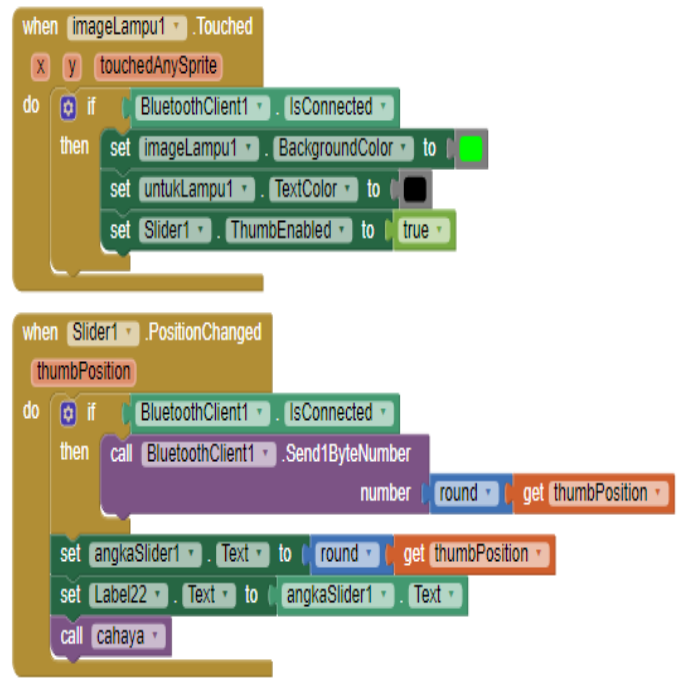

Gambar 16. Blok Programming untuk Intensitas Lampu

Gambar di atas merupakan perintah untuk mengirimkan nilai intensitas yang akan diatur oleh user, lalu mengirimkan nilai 0-255 dengan komunikasi bluetooth pada Android menggunakan Arduino UNO.

\subsection{Pengujian Logika Fuzzy pada Alat}

Pada langkah pengujian ini dilakukan proses bagaimana logika fuzzy yang dibuat dapat bekerja memberikan kontrol pergerakan apakah sesuai dengan yang diinginkan. Lampu akan menerangi ruangan sesuai nilai cahaya yang dibutuhkan apabila ada masukan dari aplikasi smartphone Android. Setelah pengujian dilakukan maka diketahui bahwa sistem kendali penerangan ruangan dapat bekerja dengan baik. Berikut Perhitungan logika fuzzy pada Arduino untuk menentukan intensitas pada lampu menggunakan fungsi trapesium:

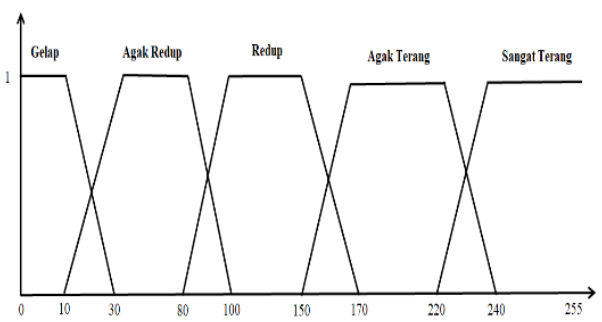

Gambar 17. Fungsi Trapesium Keanggotaan

Contoh nilai input $x=162$, dimana nilai input tersebut mempunyai nilai agak terang dan redup pada pencahayaan.

1) Hitung keanggotaan Redup: $(\mathrm{d}-\mathrm{x}) /(\mathrm{d}-\mathrm{c}), \mathrm{c} \leq \mathrm{x} \leq \mathrm{d}$, dimana $\mathrm{c}=150$ dan $\mathrm{d}=170$

$(170-162) /(170-150)=8 / 20(\mathbf{0 , 4})$

Maka nilai keanggotaan Redup adalah $\mathbf{0 , 4}$

2) Hitung keanggotaan Agak Terang:

$(\mathrm{x}-\mathrm{a}) /(\mathrm{b}-\mathrm{a}), \mathrm{a} \leq \mathrm{x} \leq \mathrm{b}$, dimana $\mathrm{a}=150$ dan $\mathrm{b}=170$

$(162-150) /(170-150)=12 / 20(0,6)$

Maka nilai keanggotaan Agak Terang adalah 0,6
Jadi, dari nilai input $\mathrm{x}=162$, nilai keanggotaan yang lebih besar yaitu Agak terang. Setelah itu dapat diputuskan bahwa intensitas cahaya lampu yaitu, Agak Terang.

\subsection{Pengujian Logika Fuzzy pada Aplikasi Android}

Pengujian akan diimplementasikan menggunakan aplikasi Android dengan angka PWM 0-255 Byte. Dari pengujian ini dapat dilihat hasil keluaran dari nilai input logika fuzzy.

"JIKA " $\mathrm{X}=\mathrm{A}$, "MAKA" $\mathrm{Y}=\mathrm{B}$

Nilaicrisp input195lux berada diantara Redup dan Terang, selanjutnya masuk ke aturan fuzzy.

Jika kondisi “Gelap“, Maka” Lampu.PWMlong

Jika kondisi "Agak Redup“, Maka"

Lampu.PWMagak_long

Jika kondisi "Redup",Maka" Lampu.PWM normal

Jika kondisi "Agak Terang",Maka"

Lampu.PWMagak_normal

Jika kondisi “Terang”,Maka" Lampu.PWMshort
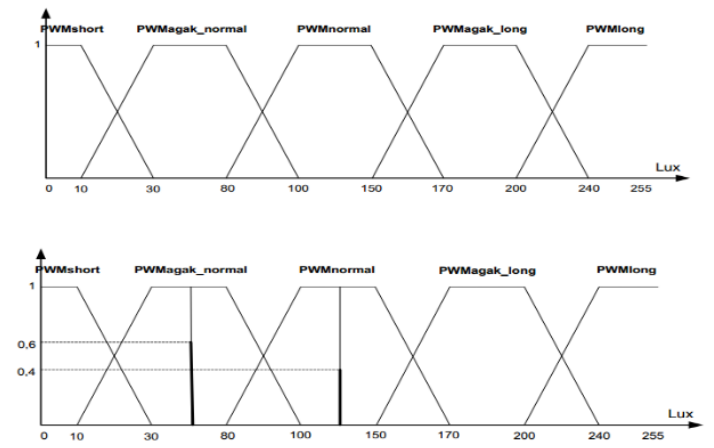

Gambar 18. Fungsi Keanggotaan Singleton untuk Output PWM

Kemudian dilakukan defuzzifikasi menggunakan Model Sugeno yang menggunakan fungsi keanggotaan yang sederhana yaitu singleton, keanggotaan yang memiliki derajat keanggotaan 1 pada suatu nilai crisp tunggal, dan 0 pada semua crisp yang lain. Metode yang digunakan Weighted Average untuk defuzzifikasi, maka:

Menghitung derajat keanggotaan Redup:

$(\mathrm{d}-\mathrm{x}) /(\mathrm{d}-\mathrm{c}), \mathrm{c} \leq \mathrm{x} \leq \mathrm{d}$, dimana $\mathrm{c}=150$ dan $\mathrm{d}=170$

$(170-162) /(170-150)=8 / 20(0,4)$

Menghitung derajat keanggotaan Agak Terang: $(\mathrm{x}-\mathrm{a}) /(\mathrm{b}-\mathrm{a}), \mathrm{a} \leq \mathrm{x} \leq \mathrm{b}$, dimana $\mathrm{a}=150$ dan $\mathrm{b}=170$ $(162-150) /(170-150)=12 / 20(0,6)$

$$
\mathrm{y} *=\frac{0,4(125)+0,6(55)}{0,4+0,6}=83 \mathrm{pwm}
$$

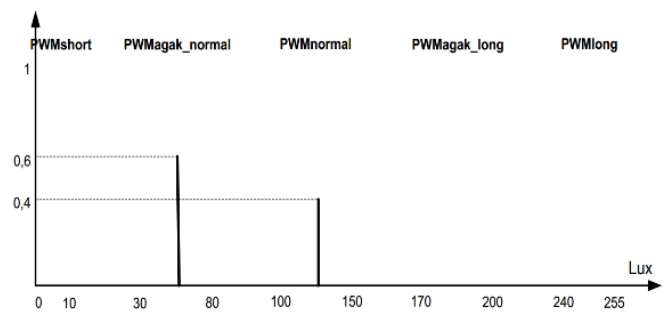

Gambar 19. Fungsi Keanggotaan Output 
Tabel 1. Hasil Uji Logika Fuzzy Pada Android

\begin{tabular}{|c|c|c|c|c|c|}
\hline $\begin{array}{l}\text { Nilai } \\
\text { Input } \\
\text { PWM }\end{array}$ & & Kea & $\begin{array}{l}\text { lai } \\
\text { gotaan }\end{array}$ & & \\
\hline $\begin{array}{c}\text { Input } \\
(\mathbf{x})\end{array}$ & $\begin{array}{c}\text { Variabel } \\
\text { Linguistik }\end{array}$ & $\begin{array}{l}c \\
\leq \\
x \\
\leq \\
d\end{array}$ & $\begin{array}{c}a \leq x \\
\leq b\end{array}$ & $\begin{array}{l}\text { Kondisi } \\
\text { Lampu }\end{array}$ & Keterangan \\
\hline 0 & Gelap & 0 & 1 & Mati & Sesuai \\
\hline 10 & Gelap & 0 & 1 & Gelap & Sesuai \\
\hline 20 & $\begin{array}{c}\text { Gelap - } \\
\text { Agak } \\
\text { Redup }\end{array}$ & 0.5 & 0.5 & Gelap & Sesuai \\
\hline 30 & $\begin{array}{l}\text { Agak } \\
\text { Redup }\end{array}$ & 0 & 1 & $\begin{array}{l}\text { Agak } \\
\text { Redup }\end{array}$ & Sesuai \\
\hline 40 & $\begin{array}{l}\text { Agak } \\
\text { Redup }\end{array}$ & 0 & 1 & $\begin{array}{l}\text { Agak } \\
\text { Redup }\end{array}$ & Sesuai \\
\hline 50 & $\begin{array}{l}\text { Agak } \\
\text { Redup }\end{array}$ & 0 & 1 & $\begin{array}{l}\text { Agak } \\
\text { Redup }\end{array}$ & Sesuai \\
\hline 60 & $\begin{array}{l}\text { Agak } \\
\text { Redup }\end{array}$ & 0 & 1 & $\begin{array}{l}\text { Agak } \\
\text { Redup }\end{array}$ & Sesuai \\
\hline 70 & $\begin{array}{l}\text { Agak } \\
\text { Redup }\end{array}$ & 0 & 1 & $\begin{array}{l}\text { Agak } \\
\text { Redup }\end{array}$ & Sesuai \\
\hline 80 & $\begin{array}{l}\text { Agak } \\
\text { Redup } \\
\text { Agak }\end{array}$ & 0 & 1 & $\begin{array}{l}\text { Agak } \\
\text { Redup }\end{array}$ & Sesuai \\
\hline 90 & $\begin{array}{l}\text { Redup - } \\
\text { Redup }\end{array}$ & 0.5 & 0.5 & Redup & Sesuai \\
\hline 100 & Redup & 0 & 1 & Redup & Sesuai \\
\hline 110 & Redup & 0 & 1 & Redup & Sesuai \\
\hline 120 & Redup & 0 & 1 & Redup & Sesuai \\
\hline 130 & Redup & 0 & 1 & Redup & Sesuai \\
\hline 140 & Redup & 0 & 1 & Redup & Sesuai \\
\hline 150 & Redup & 0 & 1 & Redup & Sesuai \\
\hline 160 & $\begin{array}{c}\text { Redup - } \\
\text { Agak } \\
\text { Terang }\end{array}$ & 0.5 & 0.5 & $\begin{array}{c}\text { Agak } \\
\text { Terang }\end{array}$ & Sesuai \\
\hline 170 & $\begin{array}{l}\text { Agak } \\
\text { Terang }\end{array}$ & 0 & 1 & $\begin{array}{c}\text { Agak } \\
\text { Terang }\end{array}$ & Sesuai \\
\hline 180 & $\begin{array}{c}\text { Agak } \\
\text { Terang }\end{array}$ & 0 & 1 & $\begin{array}{l}\text { Agak } \\
\text { Terang }\end{array}$ & Sesuai \\
\hline 200 & $\begin{array}{l}\text { Agak } \\
\text { Terang }\end{array}$ & 0 & 1 & $\begin{array}{l}\text { Agak } \\
\text { Terang }\end{array}$ & Sesuai \\
\hline 210 & $\begin{array}{c}\text { Agak } \\
\text { Terang - } \\
\text { Terang } \\
\text { Agak }\end{array}$ & $\begin{array}{c}0.7 \\
5\end{array}$ & 0.25 & $\begin{array}{c}\text { Agak } \\
\text { Terang }\end{array}$ & Sesuai \\
\hline 220 & $\begin{array}{l}\text { Terang - } \\
\text { Terang }\end{array}$ & 0.5 & 0.5 & Terang & Sesuai \\
\hline 230 & Terang & 0 & 1 & Terang & Sesuai \\
\hline 240 & Terang & 0 & 1 & Terang & Sesuai \\
\hline 250 & Terang & 0 & 1 & Terang & Sesuai \\
\hline 255 & Terang & 0 & 1 & Terang & Sesuai \\
\hline
\end{tabular}

Dari tabel pengujian dengan logika fuzzy pada Android di atas, menghasilkan sistem yang berjalan sesuai dengan control yang ada pada fuzzy. Pada sistem yang berjalan sesuai dengan apa yang diinginkan, dapat dilihat bahwa nilai PWM yang diberikan pada aplikasi Android bekerja sesuai dengan sistem logika fuzzy.

\subsection{Pengujian Blackbox}

Berikut pengujian blackbox alat secara keseluruhan pada Arduino:

Tabel 2. Pengujian Blackbox Alat Keseluruhan

\begin{tabular}{|c|c|c|c|}
\hline No & Pengujian & Kondisi & Keterangan \\
\hline 1 & $\begin{array}{l}\text { Pengujian } \\
\text { Modul } \\
\text { Bluetooth }\end{array}$ & $\begin{array}{l}\text { Bluetooth terhubung, } \\
\text { Lampu siap } \\
\text { diberikan nilai } \\
\text { intensitas }\end{array}$ & Sesuai \\
\hline 2 & $\begin{array}{l}\text { Pengujian } \\
\text { Modul } \\
\text { Bluetooth }\end{array}$ & $\begin{array}{c}\text { Mengatur Intensitas } \\
\text { Lampu Sangat } \\
\text { Terang, Lampu } \\
\text { Terang }\end{array}$ & Sesuai \\
\hline 3 & $\begin{array}{l}\text { Pengujian } \\
\text { Modul } \\
\text { Bluetooth }\end{array}$ & $\begin{array}{l}\text { Mengatur Intensitas } \\
\text { Lampu Agak Terang, } \\
\text { Lampu Agak Terang }\end{array}$ & Sesuai \\
\hline 4 & $\begin{array}{l}\text { Pengujian } \\
\text { Modul } \\
\text { Bluetooth }\end{array}$ & $\begin{array}{l}\text { Mengatur Intensitas } \\
\text { Lampu Redup, } \\
\text { Lampu Redup }\end{array}$ & Sesuai \\
\hline 5 & $\begin{array}{l}\text { Pengujian } \\
\text { Modul } \\
\text { Bluetooth }\end{array}$ & $\begin{array}{l}\text { Mengatur Intensitas } \\
\text { Lampu Agak Redup, } \\
\text { Lampu Agak Redup }\end{array}$ & Sesuai \\
\hline 6 & $\begin{array}{l}\text { Pengujian } \\
\text { Modul } \\
\text { Bluetooth }\end{array}$ & $\begin{array}{c}\text { Mengatur Intensitas } \\
\text { Lampu Gelap, } \\
\text { Lampu Gelap }\end{array}$ & Sesuai \\
\hline 7 & $\begin{array}{l}\text { Pengujian } \\
\text { Modul } \\
\text { Bluetooth }\end{array}$ & $\begin{array}{l}\text { Koneksi Bluetooth } \\
\text { Putus, Lampu tetap } \\
\text { menyala sesuai nilai } \\
\text { intensitas terakhir }\end{array}$ & Sesuai \\
\hline
\end{tabular}

Dari tabel pengujian blackbox di atas, terlihat bahwa sistem sudah berjalan sesuai rancangan kendali intensitas lampu ruangan dengan menggunakan metode logika fuzzy. Sehingga, sistem dapat mengambil keputusan secara akurat dan tepat dengan nilai input yang diterima dari smartphone Android dan modul Arduino.

\section{KESIMPULAN}

Pada bab ini merupakan bagian akhir pada penelitian kami dan kami dapat menyimpulkan hasil penelitian kami yaitu terdapat dua bagian utama perancangan, antara lain aplikasi Android mempunyai interface yang berfungsi untuk mengatur dan melihat kondisi intensitas cahaya lampu pada ruangan. Merupakan bagian dari kendali utama pada mikrokontroler Arduino UNO fungsinya untuk membaca input yang akan diverifikasi selanjutnya dilakukan perintah pinout dari Arduino UNO sesuai perintah yang diarahkan sehingga memberikan status lampu pada Android. Hasil yang didapat dari pengujian ini dapat disimpulkan bahwa Android terhubung dengan mikrokontroler dengan menggunakan koneksi bluetooth dan dapat digunakan menjadi pengendali intensitas cahaya lampu pada suatu ruangan.

\section{Ucapan Terima Kasih}

Kami mengucapkan syukur kepada ALLAH, terima kasih baik kepada pihak instansi atau Lembaga yang telah memberikan kami support sehingga pelaksanaan penelitian ini berjalan lancar sebagaimana mestinya. 


\section{DAFTAR PUSTAKA}

[1] B. Guntur and G. M. Putro, “Analisis Intensitas Cahaya Pada Area Produksi Terhadap Keselamatan Dan Kenyamanan Kerja Sesuai Dengan Standar Pencahayaan," Opsi, vol. 10, no. 2, p. 115, 2017, doi: 10.31315/opsi.v10i2.2106.

[2] M. Irfan, L. P. Ayuningtias, and J. Jumadi, “Analisa Perbandingan Logic Fuzzy Metode Tsukamoto, Sugeno, Dan Mamdani ( Studi Kasus: Prediksi Jumlah Pendaftar Mahasiswa Baru Fakultas Sains Dan Teknologi Uin Sunan Gunung Djati Bandung)," J. Tek. Inform., vol. 10, no. 1, pp. 9-16, 2018, doi: 10.15408/jti.v10i1.6810.

[3] H. Henny and S. Hapal, "Sistem Pengendali Lampu Listrik Berbasis Mikrokontroler Atmega328 Pada Smartphone Android," Simtek J. Sist. Inf. dan Tek. Komput., vol. 1, no. 1, pp. 9-14, 2016, doi: 10.51876/simtek.v1i1.2.

[4] M. S. Son, "Pengembangan Mikrokontroler Sebagai Remote Control Berbasis Android," J. Tek. Inform., vol. 11, no. 1, pp. 67-74, 2018, doi: 10.15408/jti.v11i1.6293.

[5] F. Djuandi, "Pengenalan Arduino," E-book. www. tobuku, pp. 1-24, 2011.
[6] H. Prabowo and F. Arifin, "PENGEMBANGAN MEDIA PEMBELAJARAN KENDALI FUZZY LOGIC BERBASIS ARDUINO NANO PADA MATA KULIAH PRAKTIK SISTEM," vol. 3, no. May, pp. 39-45, 2018, doi: 10.21831/elinvo.v3i1.19739.

[7] F. Wahab, A. Sumardiono, A. R. Al Tahtawi, and A. F. A. Mulayari, "Desain dan Purwarupa Fuzzy Logic Control untuk Pengendalian Suhu Ruangan," J. Teknol. Rekayasa, vol. 2, no. 1, p. 1, 2017, doi: 10.31544/jtera.v2.i1.2017.1-8.

[8] Y. S. Handayani and Y. Mardiana, "Kendali Robot Bluetooth Dengan Smartphone Android Berbasis Arduino Uno," Ilk. J. Ilm., vol. 10, no. 3, pp. 331337, 2018, doi: 10.33096/ilkom.v10i3.363.331-337.

[9] R. D. Axel, X. Najoan, B. A. Sugiarso, J. T. Elektro$\mathrm{ft}$, and M. Manado, "Rancang Bangun Aplikasi Berbasis Android Untuk Informasi Kegiatan Dan Pelayanan Gereja," J. Tek. Elektro dan Komput., vol. 6, no. 1, pp. 1-6, 2017.

[10] A. Mulyanto and Dkk, "Sistem Kendali Lampu Rumah Menggunakan," J. TEKNOINFO, vol. 11, no. 2, pp. 48-53, 2017. 